\title{
Molecular engineering of dithiafulvene organic sensitizers with pyridine acceptor for high efficiency dye-sensitized solar cells
}

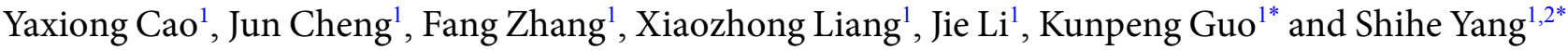

\begin{abstract}
Donor- $\pi$-acceptor (D- $\pi$-A) organic compounds have drawn keen interests as photosensitizers in dye sensitized solar cells (DSSCs). Recent studies showed that pyridine ring as an electron-withdrawing anchoring group could lead to efficient electron injection. To improve the performance of pyridine containing sensitizers based DSSCs, the electron donor, $\pi$-bridge and the whole structure should be well engineered at molecular level. In this work, we prepared two monomer type dithiafulvene based sensitizers both with a pyridine acceptor but differing in the phenyl-thienyl (DTFPy3) and thienyl-phenyl $\pi$-bridges (DTFPy4), and two corresponding dimeric congeners D-DTFPy3 and D-DTFPy4, and tested them in DSSCs. It was found that the arrangement of the electron-rich thienyl group adjacent to the electron donor moiety in the $\pi$-bridge red-shifted in the absorption, and the dimeric sensitizers exhibited significantly enhanced absorption. Among them, D-DTFPy4 garnered the highest light harvesting efficiency, yielding an overall power conversion efficiency up to $5.26 \%$.
\end{abstract}

Keywords: dye sensitized solar cells, dithiafulvene, pyridine acceptor, dimeric sensitizer

\section{INTRODUCTION}

Since the pioneering work on dye sensitized solar cells (DSSCs) by Grätzel and O'Regan in 1991 [1], many studies have focused on both material development and cell fabrication for improving the cell performance [2-18]. Over the past decades, donor- $\pi$-acceptor $(D-\pi-A)$ type organic compounds as photosensitizers have drawn keen interests due to their advantages of high molar extinction coefficients, flexible structure design, low material cost and simple preparation process [19-28]. In a typical $D-\pi-A$ organic sensitizer, cyanoacrylic acid is frequently used both as an electron acceptor and as an anchoring group for attachment to a mesoporous $\mathrm{TiO}_{2}$ surface. The carboxyl group enables a good electron communication between the sensitizer and $\mathrm{TiO}_{2}$ by forming a strong bidentate bridging linkage with Brønsted acid sites on the $\mathrm{TiO}_{2}$ surface [29-34]. Considering that the formation of coordinate bonds between the lone pair of electrons on the nitrogen atom of the pyridine ring and the Lewis acid sites of the $\mathrm{TiO}_{2}$ surface would enable efficient electron injection arising, various organic sensitizers using pyridine as an electron-withdrawing anchoring group have been prepared and studied in DSSCs [31,35-41].

One of the drawbacks of organic sensitizers with a pyridine anchoring group is their relatively narrow absorption spectrum and low absorption intensity. The optimal organic sensitizer for solar cell applications should possess a broad absorption spectrum in order to produce large photocurrent response [10]. In order to address this issue, organic sensitizers comprising electron donor, $\pi$-bridge and molecular structure should be well engineered at molecular level to meet the efficiency. For example, adjusting the $\pi$-bridge components in an organic sensitizer molecule can increase the intramolecular charge transfer (ICT) effect, and lead to red-shift of the absorption [42]. In addition, organic sensitizers bearing a monomer $\mathrm{D}-\pi$-A type structure often afford limited electron extraction. If the light-harvesting units are increased in single sensitizer molecule, the absorption bands may be broadened and the intensity

\footnotetext{
${ }^{1}$ Ministry of Education Key Laboratory of Interface Science and Engineering in Advanced Materials, Research Center of Advanced Materials Science and Technology, Taiyuan University of Technology, Taiyuan 030024, China

${ }^{2}$ Department of Chemistry, Hong Kong University of Science and Technology, Hong Kong, China

*Corresponding authors (emails: guokunpeng@tyut.edu.cn (Guo K); chsyang@ust.hk (Yang S))
} 
can be increased. Actually, among organic sensitizers using cyanoacrylic acid as acceptor, double $\mathrm{D}-\pi$-A branched sensitizers with two light-harvesting units have shown improved light response, increased photocurrent compared to its monobranched analogues $[43,44]$.

In our previous work, monobranched $\mathrm{D}-\pi-\mathrm{A}$ dithiafulvene (DTF) derivatives have shown great potential for high efficient DSSCs, owing to their well-known electron-donating ability, easy synthesis, compact dye adsorption and effective charge separation [45]. However, the strategies to improve the performance of DTF-based organic sensitizers using pyridine as electron-withdrawing anchoring group are still limited. In this work, in order to investigate how to improve the light-harvesting ability of the organic sensitizers, we prepared two monobranched DTF-based sensitizers both with a pyridine anchoring group but differing in the phenyl-thienyl (DTFPy3) and thienyl-phenyl $\pi$-bridges (DTFPy4), and, two corresponding dimeric congeners of these two monomers D-DTFPy3 and D-DTFPy4, as shown in Scheme1. By adjusting the electron rich thienyl group adjacent to the DTF donor moiety in the $\pi$-bridge, DTFPy4 exhibits absorption red-shifting compared to DTFPy3 with an electron poor phenyl group adjacent to the DTF moiety. Furthermore, after increasing the light-harvesting units, both D-DTFPy3 and D-DTFPy4 show significantly enhanced absorption intensity. Finally, D-DTFPy4 sensitized solar cells exhibit the highest power conversion efficiency $(\eta)$ of $5.26 \%$, with a short-circuit photocurrent density $\left(J_{\mathrm{sc}}\right)$ of $11.7 \mathrm{~mA} \mathrm{~cm}^{-2}$, an open-circuit photovoltage $\left(V_{\text {oc }}\right)$ of $630 \mathrm{mV}$, and a fill factor $(\mathrm{FF})$ of 0.71 , under standard global AM 1.5 solar light condition.

\section{EXPERIMENTAL SECTION}

\section{Materials}

All solvents and reagents, unless otherwise stated, were of high-purity and used as received. 4-Formylphenylboronic acid, 2-bromothiophene, 4-bromobenzaldehyde, pyridine-4-boronic acid, 5-bromo-2-thiophenecarboxaldehyde, 4-bromophenylboronic acid, triethyl phosphite and $\mathrm{Pd}\left(\mathrm{PPh}_{3}\right)_{4}$ were purchased from Energy Chemical.

\section{General}

NMR spectra $\left({ }^{1} \mathrm{H}\right.$ and $\left.{ }^{13} \mathrm{C}\right)$ were recorded at room temperature on Bruker AV $600 \mathrm{MHz}$ spectrometer. Data are listed in parts per million (ppm) on the delta scale $(\delta)$ and coupling constants were reported in Hz. The splitting patterns are designated as follows: $s$ (singlet); $d$ (doublet); $t$ (triplet); $\mathrm{q}$ (quartet); $\mathrm{m}$ (multiplet) and br (broad). Mass spectra measured on Microflex MALDI-TOF MS. UV-vis spectra of dye in solution and loading on $\mathrm{TiO}_{2}$ films were measured with a HITIACH U-3900 spectrometer at room temperature. Photoluminescent (PL) spectra were recorded in a Horiba Fluoromax 4 spectrometer. Cyclic voltammetry (CV) was carried out on a CHI600E Electrochemical Analyzer at a scan rate of $0.1 \mathrm{~V} \mathrm{~s}^{-1}$. The oxidation potential of the sensitizer was measured in dimethylformamide (DMF) with TBAPF6 $\left(0.1 \mathrm{~mol} \mathrm{~L}^{-1}\right)$ as electrolyte and glassy carbon as working electrode, $\mathrm{Ag} / \mathrm{Ag}^{+}$as reference electrode, $\mathrm{Pt}$ as counter electrode. The potential of the reference electrode was calibrated with $\mathrm{Fc} / \mathrm{Fc}^{+}$as an internal reference and converted to normal hydrogen electrode (NHE) by addition of $630 \mathrm{mV}$. Theoretical calculations using density functional theory (DFT) were performed using the Gaussian03 package at the B3LYP/6-31G* level.

\section{Synthesis}

Compound HDT (4,5-bis(hexylthio)-1,3-dithiole-2thione) was synthesized as reported in our previous work [45].

Compound 1 2-(4-formylphenyl)thiophene. 4-Formylphenylboronic acid $(1.62 \mathrm{~g}, 10.8 \mathrm{mmol})$ was treated with 2-bromothiophene $(1.47 \mathrm{~g}, 9 \mathrm{mmol})$ in the presence of $\mathrm{Pd}\left(\mathrm{PPh}_{3}\right)_{4}(326 \mathrm{mg}, 282 \mu \mathrm{mol}), 1 \mathrm{~mol} \mathrm{~L}{ }^{-1}$ aqueous solution of $\mathrm{K}_{2} \mathrm{CO}_{3}(18 \mathrm{~mL})$ and 1,2-dimethoxyethane $(70 \mathrm{~mL})$. The mixture was refluxed for $6 \mathrm{~h}$ under nitrogen atmosphere. After cooling down to room temperature, and addition of dichloromethane, the mixture was washed with water and dried on magnesium sulfate. The solvent was removed by rotary evaporation and the residue was purified by silicon gel column chromatography with petroleum ether:ethyl acetate $(6: 1, v: v)$ as eluent to afford $\mathbf{1}$ as a yellow solid (1.02 g, yield $60 \%) .{ }^{1} \mathrm{H} \mathrm{NMR}\left(600 \mathrm{MHz}, \mathrm{CDCl}_{3}, \mathrm{ppm}\right): \delta=10.01$ $(\mathrm{s}, 1 \mathrm{H}), 7.89(\mathrm{~d}, 2 \mathrm{H}, J=8.4 \mathrm{~Hz}), 7.77(\mathrm{~d}, 2 \mathrm{H}, J=8.4 \mathrm{~Hz})$, $7.47(\mathrm{~d}, 1 \mathrm{H}, J=7.2 \mathrm{~Hz}), 7.40(\mathrm{~d}, 1 \mathrm{H}, J=7.2 \mathrm{~Hz}), 7.14(\mathrm{~m}$, 1H). MALDI-TOF: $m / z[\mathrm{M}]^{+}$cacld. $\mathrm{C}_{11} \mathrm{H}_{8} \mathrm{OS}, 188.2456$; found: 188.2453 .

Compound 2 4-(5-bromothiophen-2-yl)benzaldehyde. To a stirred solution of $\mathbf{1}(2.0 \mathrm{~g}, 10.6 \mathrm{mmol})$ in $20 \mathrm{~mL}$ of tetrahydrofuran (THF) in a $100 \mathrm{~mL}$ flask was slowly added $\mathrm{N}$-bromosuccinimide $(2.27 \mathrm{~g}, 12.8 \mathrm{mmol})$ and acetic acid $(20 \mathrm{~mL})$. After the addition, the mixture was stirred at room temperature for $4 \mathrm{~h}$ until TLC showed no starting material left. The mixture was washed with water, dried with anhydrous magnesium sulfate, and filtered. The product was obtained after evaporation of the solvent and dried in vacuum to afford 2 as white solid $(2.52 \mathrm{~g}$, yield: $88 \%) .{ }^{1} \mathrm{H}$ NMR $\left(600 \mathrm{MHz}, \mathrm{CDCl}_{3}, \mathrm{ppm}\right): \delta=10.00(\mathrm{~s}$, 
$1 \mathrm{H}), 7.88(\mathrm{~d}, 2 \mathrm{H}, J=8.2 \mathrm{~Hz}), 7.67(\mathrm{~d}, 2 \mathrm{H}, J=8.2 \mathrm{~Hz}), 7.21$ (d, $1 \mathrm{H}, J=3.9 \mathrm{~Hz}), 7.09$ (d, $1 \mathrm{H}, J=3.9 \mathrm{~Hz})$. MALDI-TOF: $m / z[\mathrm{M}]^{+}$cacld. $\mathrm{C}_{11} \mathrm{H}_{7} \mathrm{BrOS}, 265.9401$; found: 265.9399 .

Compound 3 4-(5-(pyridin-4-yl)thiophen-2-yl)benzaldehyde. Pyridine-4-boronic acid (1.11 g, $9 \mathrm{mmol}$ ) was treated with $2(0.9 \mathrm{~g}, 3.4 \mathrm{mmol})$ in the presence of $\mathrm{Pd}\left(\mathrm{PPh}_{3}\right)_{4}(145 \mathrm{mg}, 125 \mu \mathrm{mol}), 1 \mathrm{~mol} \mathrm{~L}^{-1}$ aqueous solution of $\mathrm{K}_{2} \mathrm{CO}_{3}(15 \mathrm{~mL})$ and 1,2-dimethoxyethane $(75 \mathrm{~mL})$. The mixture was refluxed for $6 \mathrm{~h}$ under nitrogen atmosphere. After cooling down to room temperature, and addition of dichloromethane, the mixture was washed with water and dried on magnesium sulfate. The solvent was removed by rotary evaporation and the residue was purified by silicon gel column chromatography with petroleum ether:ethyl acetate $(6: 1, v: v)$ as eluent to afford 3 as a yellow solid (538 mg, yield 60\%). ${ }^{1} \mathrm{H} \mathrm{NMR}\left(600 \mathrm{MHz}, \mathrm{CDCl}_{3}, \mathrm{ppm}\right): \delta=$ $10.03(\mathrm{~s}, 1 \mathrm{H}), 8.64(\mathrm{~d}, 2 \mathrm{H}, J=6.1 \mathrm{~Hz}), 7.93(\mathrm{~d}, 2 \mathrm{H}, J=8.4$ $\mathrm{Hz}), 7.80(\mathrm{~d}, 2 \mathrm{H}, J=8.3 \mathrm{~Hz}), 7.54(\mathrm{~d}, 1 \mathrm{H}, J=3.9 \mathrm{~Hz}), 7.51$ $(\mathrm{d}, 2 \mathrm{H}, J=6.8 \mathrm{~Hz}), 7.49$ (d, $1 \mathrm{H}, J=3.9 \mathrm{~Hz})$. MALDI-TOF: $m / z[\mathrm{M}]^{+}$cacld. $\mathrm{C}_{16} \mathrm{H}_{11} \mathrm{NOS}, 265.0561$; found: 265.0559 .

Compound 4 5-(4-bromophenyl)thiophene-2-carbaldehyde. 4-Bromophenylboronic acid (1.93 g, $9.6 \mathrm{mmol}$ ) was treated with 5-bromo-2-thiophenecarboxaldehyde (1.53 g, $8 \mathrm{mmol})$ in the presence of $\mathrm{Pd}\left(\mathrm{PPh}_{3}\right)_{4}(290 \mathrm{mg}, 250 \mu \mathrm{mol})$, $1 \mathrm{~mol} \mathrm{~L}{ }^{-1}$ aqueous solution of $\mathrm{K}_{2} \mathrm{CO}_{3}(20 \mathrm{~mL})$ and 1,2dimethoxyethane $(90 \mathrm{~mL})$. The mixture was refluxed for 6 $\mathrm{h}$ under nitrogen atmosphere. After cooling down to room temperature, and addition of dichloromethane, the mixture was washed with water and dried on magnesium sulfate. The solvent was removed by rotary evaporation and the residue was purified by silicon gel column chromatography with petroleum ether:ethyl acetate $(6: 1, v: v)$ as eluent to afford 4 as yellow solid (576 mg, yield 27\%). ${ }^{1} \mathrm{H}$ NMR (600 $\left.\mathrm{MHz}, \mathrm{CDCl}_{3}, \mathrm{ppm}\right): \delta=9.90(\mathrm{~s}, 1 \mathrm{H}), 7.74(\mathrm{~d}, 1 \mathrm{H}, J=3.9$ $\mathrm{Hz}), 7.57(\mathrm{~d}, 2 \mathrm{H}, J=8.7 \mathrm{~Hz}), 7.54(\mathrm{~d}, 2 \mathrm{H}, J=8.8 \mathrm{~Hz}), 7.40(\mathrm{~d}$, $1 \mathrm{H}, J=3.9 \mathrm{~Hz})$. MALDI-TOF: $m / z[\mathrm{M}]^{+}$cacld. $\mathrm{C}_{11} \mathrm{H}_{7} \mathrm{BrOS}$, 265.9401; found: 265.9398.

Compound 5 5-(4-(pyridin-4-yl)phenyl)thiophene-2carbaldehyde. Pyridine-4-boronic acid (369 mg, $3.0 \mathrm{mmol}$ ) was treated with $4(548 \mathrm{mg}, 2.5 \mathrm{mmol})$ in the presence of $\mathrm{Pd}\left(\mathrm{PPh}_{3}\right)_{4}(92 \mathrm{mg}, 79 \mu \mathrm{mol}), 1 \mathrm{~mol} \mathrm{~L}{ }^{-1}$ aqueous solution of $\mathrm{K}_{2} \mathrm{CO}_{3}(4 \mathrm{~mL})$ and 1,2-dimethoxyethane $(30 \mathrm{~mL})$. The mixture was refluxed for $6 \mathrm{~h}$ under nitrogen atmosphere. After cooling down to room temperature, and addition of dichloromethane, the mixture was washed with water and dried on magnesium sulfate. The solvent was removed by rotary evaporation and the residue was purified by silicon gel column chromatography with petroleum ether:ethyl acetate $(6: 1, v: v)$ as eluent to afford 5 as a yellow solid (330 mg, yield 49\%). ${ }^{1} \mathrm{H}$ NMR (600 $\left.\mathrm{MHz}, \mathrm{CDCl}_{3}, \mathrm{ppm}\right): \delta=$ $9.93(\mathrm{~s}, 1 \mathrm{H}) ; 8.70(\mathrm{~d}, 2 \mathrm{H}, J=6.1 \mathrm{~Hz}) ; 7.81(\mathrm{~d}, 2 \mathrm{H}, J=8.6$ $\mathrm{Hz}) ; 7.79(\mathrm{~d}, 1 \mathrm{H}, J=3.9 \mathrm{~Hz}) ; 7.73(\mathrm{~d}, 2 \mathrm{H}, J=8.6 \mathrm{~Hz}) ; 7.54$ $(\mathrm{d}, 2 \mathrm{H}, J=6.1 \mathrm{~Hz}) ; 7.49$ (d, $1 \mathrm{H}, J=3.9 \mathrm{~Hz})$. MALDI-TOF: $m / z[\mathrm{M}]^{+}$cacld. $\mathrm{C}_{16} \mathrm{H}_{11} \mathrm{NOS}, 265.0561$; found: 265.0558 .

Compound DTFPy3 4-(5-(4-((4,5-bis(hexylthio)-1,3dithiol-2-ylidene)methyl)phenyl)thiophen-2-yl)pyridine.

HDT (878.4 mg, $2.4 \mathrm{mmol}$ ) and 3 (400 mg, $1.51 \mathrm{mmol}$ ) were dissolved in $20 \mathrm{~mL}$ of boiling toluene under nitrogen atmosphere, then $\mathrm{P}(\mathrm{OEt})_{3}(7 \mathrm{~mL})$ was added. The resulting mixture was refluxed for $3 \mathrm{~h}$. After cooling and addition of dichloromethane, the mixture was washed with brine and dried on magnesium sulfate. The solvent was removed by rotary evaporation and the residue was purified by silicon gel column chromatography with petroleum ether:ethyl acetate $(4: 1, v: v)$ as eluent to afford DTFPy3 as an orange solid (626 mg, yield 71\%). ${ }^{1} \mathrm{H} \mathrm{NMR}\left(600 \mathrm{MHz}, \mathrm{CDCl}_{3}\right.$, ppm) : $\delta=8.60(\mathrm{~d}, 2 \mathrm{H}, J=6.0 \mathrm{~Hz}) ; 7.63(\mathrm{~d}, 2 \mathrm{H}, J=8.4$ $\mathrm{Hz}) ; 7.49(\mathrm{~d}, 1 \mathrm{H}, J=3.8 \mathrm{~Hz}) ; 7.48(\mathrm{~d}, 2 \mathrm{H}, J=6.8 \mathrm{~Hz}) ; 7.33$ $(\mathrm{d}, 1 \mathrm{H}, J=3.8 \mathrm{~Hz}) ; 7.25(\mathrm{~d}, 2 \mathrm{H}, J=8.4 \mathrm{~Hz}) ; 6.48(\mathrm{~s}, 1 \mathrm{H})$; $2.84(\mathrm{t}, 4 \mathrm{H}, J=7.4 \mathrm{~Hz}) ; 1.66(\mathrm{~m}, 4 \mathrm{H}) ; 1.43(\mathrm{~m}, 4 \mathrm{H}) ; 1.32$ $(\mathrm{m}, 8 \mathrm{H}) ; 0.90(\mathrm{t}, 6 \mathrm{H}) .{ }^{13} \mathrm{C} \mathrm{NMR}\left(151 \mathrm{MHz}, \mathrm{CDCl}_{3}, \mathrm{ppm}\right)$ : $\delta=153.33 ; 148.91 ; 144.14 ; 139.13 ; 136.49 ; 133.72 ; 130.76$; $129.34 ; 128.76 ; 127.75 ; 126.93 ; 122.35 ; 116.37 ; 106.77$; $39.06 ; 34.24 ; 32.65 ; 31.15 ; 25.44 ; 16.91$. MALDI-TOF: $\mathrm{m} / z$ $[\mathrm{M}]^{+}$cacld. $\mathrm{C}_{31} \mathrm{H}_{37} \mathrm{NS}_{5}, 583.9572$; found: 583.9569 .

Compound DTFPy4 4-(4-(5-((4,5-bis(hexylthio)-1,3dithiol-2-ylidene)methyl)thiophen-2-yl)phenyl)pyridine. A procedure similar to that for synthesizing compound DTFPy3 was followed but using compound 5 (400 mg, 1.5 $\mathrm{mmol}$ ) instead of compound 3. After removing the solvent, the residue underwent recrystallization from acetone and gave DTFPy4 as an orange solid (495 mg, yield 56\%). ${ }^{1} \mathrm{H}$ NMR $\left(600 \mathrm{MHz}, \mathrm{CDCl}_{3}, \mathrm{ppm}\right): \delta=8.67(\mathrm{~d}, 2 \mathrm{H}, J=6.0$ $\mathrm{Hz}) ; 7.72(\mathrm{~d}, 2 \mathrm{H}, J=8.4 \mathrm{~Hz}) ; 7.66(\mathrm{~d}, 2 \mathrm{H}, J=8.4 \mathrm{~Hz}) ; 7.53$ $(\mathrm{d}, 2 \mathrm{H}, J=6.1 \mathrm{~Hz}) ; 7.34(\mathrm{~d}, 1 \mathrm{H}, J=3.8 \mathrm{~Hz}) ; 6.86(\mathrm{~d}, 1 \mathrm{H}, J=$ $4.4 \mathrm{~Hz}) ; 6.68$ (s, $1 \mathrm{H}) ; 2.86(\mathrm{t}, 4 \mathrm{H}, J=7.2 \mathrm{~Hz}) ; 1.67(\mathrm{~m}, 4 \mathrm{H})$; $1.43(\mathrm{~m}, 4 \mathrm{H}) ; 1.31(\mathrm{~m}, 8 \mathrm{H}) ; 0.90(\mathrm{t}, 6 \mathrm{H}) .{ }^{13} \mathrm{C}-\mathrm{NMR}(151$ $\left.\mathrm{MHz}, \mathrm{CDCl}_{3}, \mathrm{ppm}\right): \delta=149.32 ; 146.49 ; 140.37 ; 139.70$; $135.49 ; 134.12 ; 130.75 ; 127.59 ; 126.41 ; 124.87 ; 124.01$; $123.04 ; 120.17 ; 106.77 ; 35.30 ; 30.33 ; 28.72 ; 27.23 ; 21.54$; 13.03. MALDI-TOF: $m / z[\mathrm{M}]^{+}$cacld. $\mathrm{C}_{31} \mathrm{H}_{37} \mathrm{NS}_{5}$ : 583.9572 . Found: 583.9570.

Compound D-DTFPy3 4-(5-(4-(1,2-bis(4,5-bis (hexylthio)-1,3-dithiol-2-ylidene)-2-(4-(5-(pyridin-4-yl) thiophen-2-yl) phenyl)ethyl)phenyl)thiophen-2-yl)pyridine. DTFPy3 (500 mg, $0.86 \mathrm{mmol}$ ) and iodine $(654 \mathrm{mg}$, $2.57 \mathrm{mmol})$ were added in dichloromethane $(20 \mathrm{~mL})$, and the mixture was stirred at room temperature for $5 \mathrm{~h}$. A 
saturated aqueous solution of $\mathrm{Na}_{2} \mathrm{~S}_{2} \mathrm{O}_{3}$ was added, and the resulting mixture was stirred at room temperature for another $1 \mathrm{~h}$. The organic layer was separated, washed with $\mathrm{H}_{2} \mathrm{O}$, dried over $\mathrm{MgSO}_{4}$. The solvents were removed by rotary evaporation and the residue was purified by silicon gel column chromatography with petroleum ether:ethyl acetate $(4: 1, v: v)$ as eluent to afford D-DTFPy 3 as a brown semisolid (320 mg, yield 64\%). ${ }^{1} \mathrm{H} \mathrm{NMR}\left(600 \mathrm{MHz}, \mathrm{CDCl}_{3}\right.$, ppm) : $\delta=8.59(\mathrm{~d}, 4 \mathrm{H}, J=6.0 \mathrm{~Hz}) ; 7.61(\mathrm{~d}, 4 \mathrm{H}, J=8.4 \mathrm{~Hz})$; $7.48(\mathrm{~d}, 2 \mathrm{H}, J=3.8 \mathrm{~Hz}) ; 7.46(\mathrm{~m}, 8 \mathrm{H}) ; 7.31(\mathrm{~d}, 2 \mathrm{H}, J=3.8$ $\mathrm{Hz}) ; 2.85$ (t, 4H, $J=7.2 \mathrm{~Hz}) ; 2.77(\mathrm{t}, 4 \mathrm{H}, J=7.2 \mathrm{~Hz}) ; 1.66$ $(\mathrm{m}, 6 \mathrm{H}) ; 1.59(\mathrm{~m}, 6 \mathrm{H}) ; 1.43(\mathrm{~m}, 4 \mathrm{H}) ; 1.32(\mathrm{~m}, 8 \mathrm{H}) ; 1.26$ $(\mathrm{m}, 8 \mathrm{H}) ; 0.90(\mathrm{t}, 6 \mathrm{H}) ; 0.86(\mathrm{t}, 6 \mathrm{H}) .{ }^{13} \mathrm{C}-\mathrm{NMR}(151 \mathrm{MHz}$, $\left.\mathrm{CDCl}_{3}, \mathrm{ppm}\right): \delta=149.56 ; 146.24 ; 141.87 ; 139.51 ; 137.98$; $136.87 ; 131.65 ; 129.04 ; 127.28 ; 127.03 ; 126.85 ; 126.05$; $125.97 ; 124.24 ; 119.60 ; 36.18 ; 35.98 ; 31.32 ; 31.18 ; 29.65$; $29.59 ; 28.21 ; 22.52 ; 22.38 ; 14.03 ; 13.97$. MALDI-TOF: $\mathrm{m} / \mathrm{z}$ $[\mathrm{M}]^{+}$cacld. $\mathrm{C}_{62} \mathrm{H}_{72} \mathrm{~N}_{2} \mathrm{~S}_{10}, 1164.2903$; found: 1164.2901.

Compound D-DTFPy4 4-(4-(5-(1,2-bis(4,5bis(hexylthio)-1,3-dithiol-2-ylidene)-2-(5-(4-

(pyridin-4-yl)phenyl)thiophen $\quad-2$-yl)ethyl)thiophen-2-yl)phenyl)pyridine. A procedure similar to that for synthesizing compound D-DTFPy3 was followed but using compound DTFPy4 (700 mg, $1.20 \mathrm{mmol}$ ) instead of compound DTFPy3. After removing the solvents, the residue was purified by silicon gel column chromatography with petroleum ether:ethyl acetate $(4: 1, v: v)$ as eluent to afford D-DTFPy4 as an dark-red solid (480 $\mathrm{mg}$, yield 68\%). ${ }^{1} \mathrm{H}$ NMR $\left(600 \mathrm{MHz}, \mathrm{CDCl}_{3}, \mathrm{ppm}\right): \delta=8.66(\mathrm{~d}$, $4 \mathrm{H}, J=6.0 \mathrm{~Hz}) ; 7.71(\mathrm{~d}, 4 \mathrm{H}, J=8.4 \mathrm{~Hz}) ; 7.64(\mathrm{~d}, 4 \mathrm{H}, J=$ $8.4 \mathrm{~Hz}) ; 7.52(\mathrm{~d}, 4 \mathrm{H}, J=6.0 \mathrm{~Hz}) ; 7.33(\mathrm{~d}, 2 \mathrm{H}, J=4.2 \mathrm{~Hz})$; $6.96(\mathrm{~d}, 2 \mathrm{H}, J=4.2 \mathrm{~Hz}) ; 2.93(\mathrm{t}, 4 \mathrm{H}, J=7.2 \mathrm{~Hz}) ; 2.80(\mathrm{t}$, $4 \mathrm{H}, J=7.2 \mathrm{H} \mathrm{z}) ; 1.72(\mathrm{~m}, 4 \mathrm{H}) ; 1.60(\mathrm{~m}, 12 \mathrm{H}) ; 1.48(\mathrm{~m}$, $4 \mathrm{H}) ; 1.34(\mathrm{~m}, 12 \mathrm{H}) ; 0.92(\mathrm{t}, 6 \mathrm{H}) ; 0.84(\mathrm{t}, 6 \mathrm{H}) .{ }^{13} \mathrm{C}-\mathrm{NMR}$ $\left(151 \mathrm{MHz}, \mathrm{CDCl}_{3}, \mathrm{ppm}\right): \delta=150.17 ; 147.61 ; 141.52$; $140.27 ; 136.62 ; 136.42 ; 135.18 ; 130.63 ; 127.37 ; 126.32$; $125.98 ; 125.05 ; 124.35 ; 121.19 ; 118.14 ; 36.44 ; 36.07 ; 31.38$; $31.29 ; 29.71 ; 29.59 ; 28.27 ; 28.16 ; 22.57 ; 22.49 ; 14.08 ; 14.01$. MALDI-TOF: $m / z[\mathrm{M}]^{+}$cacld. $\mathrm{C}_{62} \mathrm{H}_{72} \mathrm{~N}_{2} \mathrm{~S}_{10}, 1164.2903$; found: 1164.2900 .

\section{DSSCs fabrication and photovoltaic measurements}

The preparation of DSSCs photoanode and electrolyte followed the previous literature [45]. In cell assembly, the sensitizers were loaded onto the $\mathrm{TiO}_{2}(\sim 14 \mu \mathrm{m}$ thick) film by immersion into its THF solutions $\left(0.2 \mathrm{mmol} \mathrm{L}^{-1}\right.$ dye $)$ without any co-absorbants for $30 \mathrm{~h}$ at room temperature. Before drying under vacuum, the films were rinsed with acetonitrile to remove the unabsorbed sensitizers multiple times until the solution became clear. Then, the films were assembled into a solar cell together with a Pt-sputtered FTO counter electrode and acetonitrile/valeronitrile (85:15, volume ratio) electrolyte containing $0.6 \mathrm{~mol} \mathrm{~L}^{-1} 1,2$-dimethyl3-propylimidazoliumiodide, $0.03 \mathrm{~mol} \mathrm{~L}^{-1} \mathrm{I}_{2}, 0.1 \mathrm{~mol} \mathrm{~L}^{-1}$ guanidinium thiocyanate, and $0.5 \mathrm{~mol} \mathrm{~L}^{-1} 4$-tertbutylpyridine. The active area of the photoanode film for the DSSC performance test was typically $0.25 \mathrm{~cm}^{2}$.

The photocurrent density-voltage $(J-V)$ characteristics curves were measured by the Newport PVIV-3A system. The light source (Oriel solar simulator, $450 \mathrm{~W}$ Xe lamp, AM 1.5 global filter) was calibrated to 1 sun $(100 \mathrm{~mW}$ $\mathrm{cm}^{-2}$ ). Incident photon to current efficiency (IPCE) was measured at varying wavelengths $(350-750 \mathrm{~nm})$ with an interval of $5 \mathrm{~nm}$. Nyquist spectroscopy was measured on the electrochemical workstation (Zahner, Zennium) with a frequency response analyzer under an intensity modulated $\left(5-70 \mathrm{~W} \mathrm{~m}^{-2}\right)$ light emitting diode $(525 \mathrm{~nm})$ driven by a Zahner (PP211) source supply. The frequency range was set from $100 \mathrm{KHz}$ to $0.1 \mathrm{~Hz}$.

\section{RESULTS AND DISCUSSION}

\section{Synthesis}

The synthetic routes of monomeric DTFPy3 and DTFPy4, and, dimeric D-DTFPy3 and D-DTFPy4 are depicted in Scheme 1. Bromide aromatic aldehydes $\mathbf{2}$ and $\mathbf{4}$ reacted with pyridine-4-boronic acid via Suzuki coupling to give the key intermediate aldehydes $\mathbf{3}$ and $\mathbf{5}$, respectively. Compounds 3 and $\mathbf{5}$ were then subjected to a phosphite-induced Horner-Wittig condensation with thione HDT to produce monomeric DTFPy3 and DTFPy4. With the monomers in hand, iodine-induced oxidative dimerization reactions were undertaken in dichloromethane at room temperature. The crude products of the dimerization reactions D-DTFPy3 and D-DTFPy4 were obtained after a brief reductive aqueous workup with $\mathrm{Na}_{2} \mathrm{~S}_{2} \mathrm{O}_{3}$. Column chromatographic purification then afforded dimeric D-DTFPy3 and D-DTFPy4 as brown semisolid and dark-red solid, respectively. The molecular structures of these compounds were characterized on the basis of ${ }^{1} \mathrm{H}$ $\mathrm{NMR},{ }^{13} \mathrm{C}$ NMR and mass spectra.

\section{Optical and electrochemical properties}

The UV-Vis absorption spectra of these sensitizers in dilute THF are shown in Fig. 1a and the corresponding spectroscopic parameters extracted are summarized in Table 1. All of the sensitizers exhibit strong absorption bands in the range of 400-450 $\mathrm{nm}$ and weak bands around $300-350 \mathrm{~nm}$. 

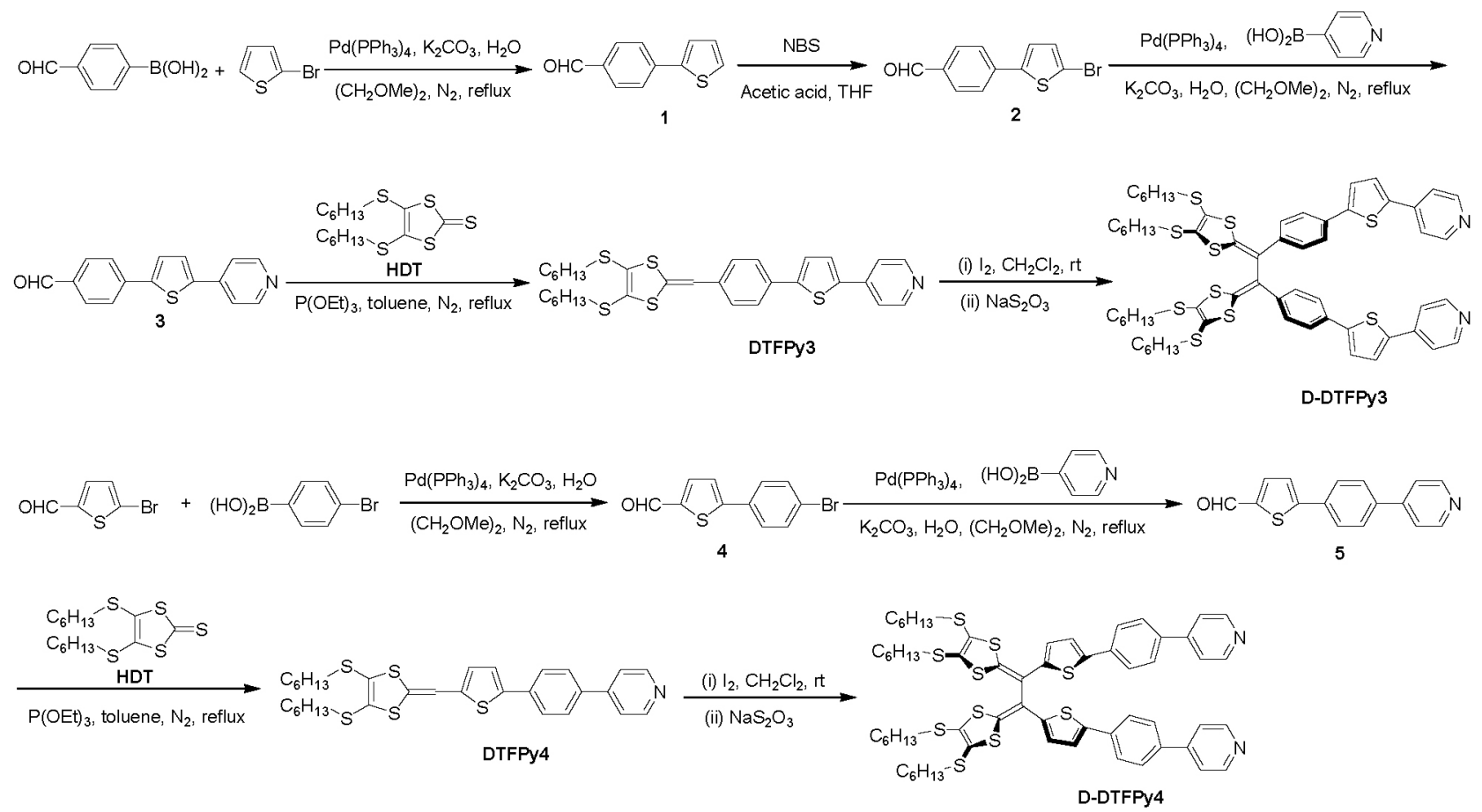

Scheme 1 Synthetic routes of DTFPy3, DTFPy4, D-DTFPy3 and D-DTFPy4.
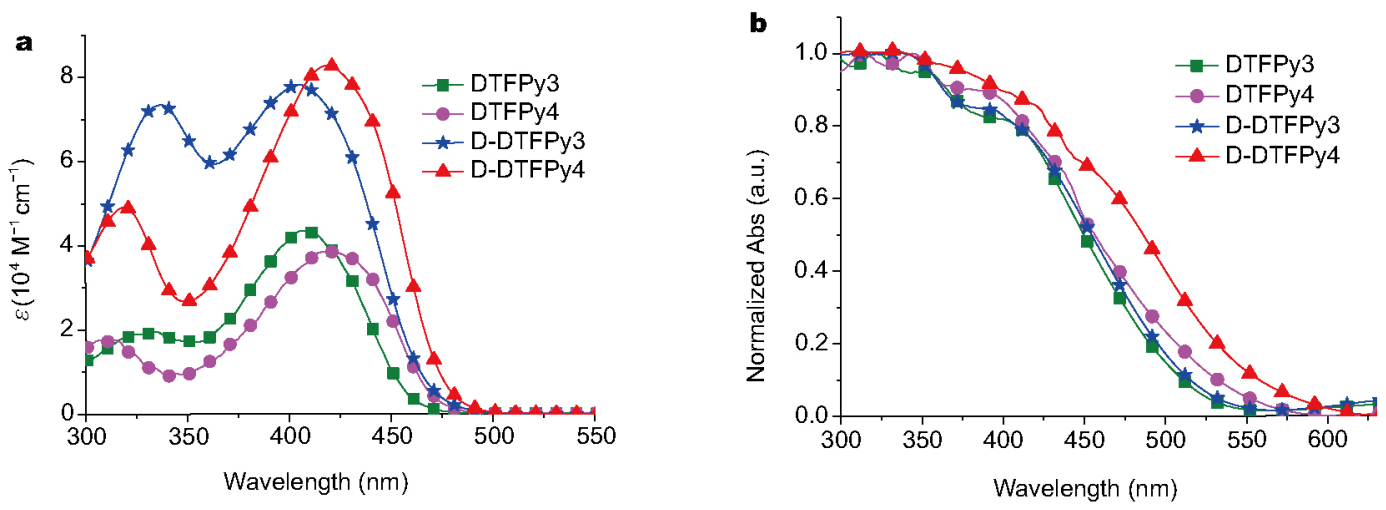

Figure 1 (a) UV-vis spectra of DTFPy3, DTFPy4, D-DTFPy3 and D-DTFPy4 in dilute THF solution $\left(1 \times 10^{-5} \mathrm{~mol} \mathrm{~L}^{-1}\right)$, and (b) normalized UV-vis spectra of DTFPy3, DTFPy4, D-DTFPy3 and D-DTFPy4 on $\mathrm{TiO}_{2}$ films.

Table 1 Optical and electrochemical properties of DTFPy3, DTFPy4, D-DTFPy3 and D-DTFPy4

\begin{tabular}{ccccccc}
\hline Sensitizer & $\lambda_{\max }^{\text {abs }}(\mathrm{nm})$ & $\varepsilon\left(\mathrm{L} \mathrm{mol}^{-1} \mathrm{~cm}^{-1}\right)$ & $\lambda_{\max }^{\mathrm{ems}}(\mathrm{nm})$ & $E_{\mathrm{ox}}(\mathrm{V} v s . \mathrm{NHE})$ & $E_{0-0}^{\mathrm{abbs} / \mathrm{ems}}(\mathrm{eV})$ & $\begin{array}{c}E_{\text {ox }}-E_{0-0} \\
(\mathrm{~V} v s . \mathrm{NHE})\end{array}$ \\
\hline DTFPy & 407 & $4.35 \times 10^{4}$ & 514 & 1.23 & 2.71 & -1.48 \\
DTFPy4 & 417 & $3.85 \times 10^{4}$ & 507 & 1.22 & 2.69 & -1.47 \\
D-DTFPy3 & 405 & $7.82 \times 10^{4}$ & 503 & 1.09 & 2.78 & 0.888 \\
D-DTFPy4 & 419 & $8.27 \times 10^{4}$ & 506 & 1.10 & 2.70 & -1.69 \\
\hline
\end{tabular}

The weak absorption bands are assigned to a more localized aromatic $\pi-\pi^{*}$ transition, and the strong absorption bands are attributed to the ICT effect between the donor and acceptor. The absorption maximum $\left(\lambda_{\max }\right)$ was observed at
$407 \mathrm{~nm}$ (molar extinction coefficient $\varepsilon=4.35 \times 10^{4} \mathrm{~L} \mathrm{~mol}^{-1}$ $\left.\mathrm{cm}^{-1}\right)$ for DTFPy3 and $417 \mathrm{~nm}\left(\varepsilon=3.85 \times 10^{4} \mathrm{~L} \mathrm{~mol}^{-1} \mathrm{~cm}^{-1}\right)$ for DTFPy4. Such a bathochromic shift of DTFPy4 can be attributed to the adjusted electron-rich thienyl group adja- 
cent to the donor part in the $\pi$-bridge. After increasing the light-harvesting units, as expected, the dimeric D-DTFPy3 and D-DTFPy4 possess broader and more intensive absorption in the ultraviolet and visible region, which could produce a higher $J_{\mathrm{sc}}$ in the DSSCs. The $\varepsilon$ of D-DTFPy 3 $\left(7.82 \times 10^{4} \mathrm{~L} \mathrm{~mol}^{-1} \mathrm{~cm}^{-1}\right)$ and D-DTFPy4 $\left(8.27 \times 10^{4} \mathrm{~L} \mathrm{~mol}^{-1}\right.$ $\mathrm{cm}^{-1}$ ) are much higher than those of their monomers in the range of 400-500 $\mathrm{nm}$, indicating that the dimeric sensitizers have good light-harvesting ability. While the trend of extinction coefficient is plausible, the $\lambda_{\max }$ for D-DTFPy3 $(405 \mathrm{~nm})$ and D-DTFPy4 $(419 \mathrm{~nm})$ are similar to that of DTFPy3 and DTFPy4, which indicates the ICT effect is not impacted by dimerization.

The profiles of the absorption spectra of $\mathrm{TiO}_{2}$ films $(4 \mu \mathrm{m})$ with these sensitizers loading show dramatically broaden and red-shift absorption relative to their solution spectra, as shown in Fig. 1b. These observations can be related to the formation of $J$-aggregates of these sensitizers on the $\mathrm{TiO}_{2}$ surfaces. The broadened absorption band and the red-shifted absorption onset on the thin film afford increased light harvesting. Especially, D-DTFPy4 possesses the broadest light response range among the four sensitizers, and thus is expected to yield improved performance for DSSCs.

The molecular orbital energy levels of the sensitizers were derived from CV (Fig. S1) in combination with the excitation transition energies $\left(E_{0-0}\right)$ determined by the intersection of absorption and photoluminescence spectra (Fig. S2), and are presented in Table 1. The first oxidation potentials $\left(E_{\mathrm{ox}}\right)$ of the ground state of DTFPy3, DTFPy4, D-DTFPy 3 and D-DTFPy4 are corresponding to their highest occupied molecular orbit (HOMO) levels. It was found that the HOMO levels of the dimeric sensitizers D-DTFPy 3 and D-DTFPy4 are slightly higher than that of monomeric sensitizers DTFPy3 and DTFPy4. All of the HOMO levels of these four sensitizers are more positive than the iodide/triiodide couple $(0.40 \mathrm{~V} v s$. NHE), indicating a thermodynamically downhill regeneration of the photo oxidized sensitizers by accepting electrons from the surrounding $\mathrm{I}^{-}$ions. The lowest unoccupied molecular orbit (LUMO) levels of DTFPy3, DTFPy4, D-DTFPy3 and D-DTFPy4, calculated as $E_{0 x}-E_{0-0}$, are sufficiently negative relative to the conduction-band edge of $\mathrm{TiO}_{2}$ $(-0.5 \mathrm{~V}$ vs. NHE), ensuring an efficient excite electron injection driving force.

\section{Theoretical calculations}

In order to understand the photo-induced charge separation of DTFPy3, DTFPy4, D-DTFPy3 and D-DTFPy4, the time dependent density functional (TD-DFT) calculations were performed on electron-density distribution of the HOMOs and LUMOs of the four sensitizers. To facilitate the calculation, the hexyl chains were replaced by methyl groups. As shown in Fig. 2, the HOMO electron density for the sensitizers is mainly located at the electron-donor part and the adjacent aromatic rings, while the electron density of LUMO is transferred to the pyridine acceptor unit. More obvious electron density separation going from DTFPy3 to DTFPy4 and D-DTFPy3 to D-DTFPy4 is observed, which explains the red-shifted absorption of DTFPy4 and D-DTFPy4 with the featured $\pi$-bridge arrangement. It demonstrates that the 4-pyridyl group is predominantly adsorbed onto the $\mathrm{TiO}_{2}$ through coordinate bond between the pyridyl group and the Lewis-acidic sites on the $\mathrm{TiO}_{2}$ surface. Therefore upon photo-excitation, the electron density is redistributed in the LUMO moving towards the pyridine moiety anchored on $\mathrm{TiO}_{2}$ and the $\pi$-bridge arrangement in DTFPy4 and D-DTFPy4 appears to be more desirable for the required charge separation in DSSCs.

Furthermore, the light harvesting efficiencies (LHEs) of the four sensitizers were calculated using the oscillator strengths obtained by the TD-DFT calculation. The sensitizers with high LHE generally ensure a better photocurrent response. From Table 1, it is found that the LHE

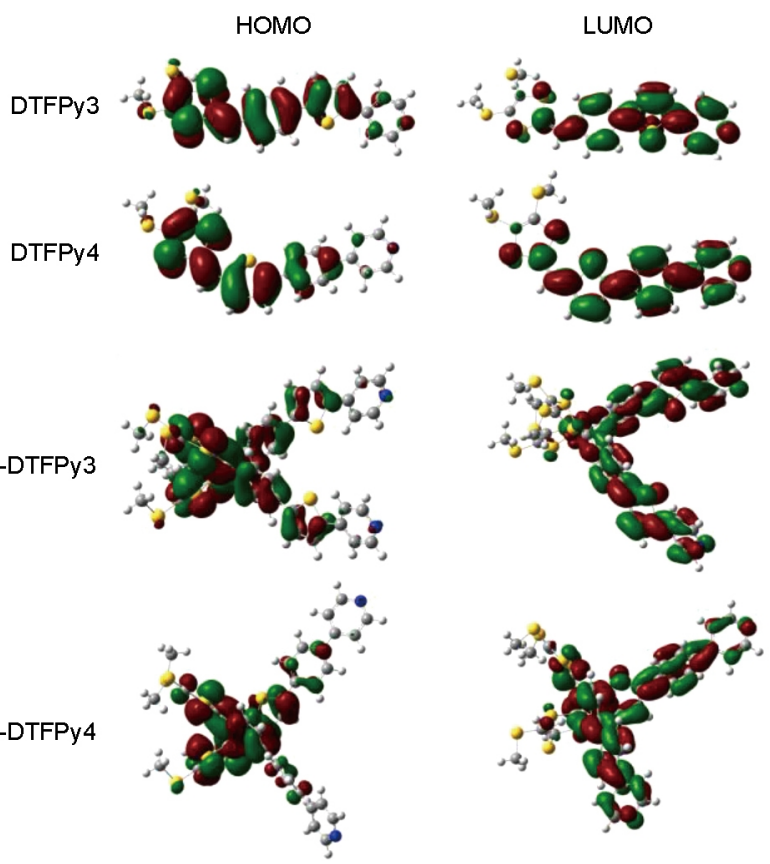

Figure 2 Electron-density distributions for the HOMOs and LUMOs of the DTFPy3, DTFPy4, D-DTFPy3 and D-DTFPy4. 
becomes greater with the increase of the light-harvesting units from DTFPy3 and DTFPy4 to D-DTFPy3 and D-DTFPy4, as reflected by the increase in LHE from 0.888 to 0.962 . This finding clearly indicates that the dimeric sensitizers D-DTFPy4 afford the best LHE and highest $J_{\mathrm{sc}}$.

\section{Photovoltaic properties}

The $J-V$ characteristics of the solar cells sensitized with sensitizers DTFPy3, DTFPy4, D-DTFPy3 and D-DTFPy4 measured under standard AM 1.5G conditions $(100 \mathrm{~mW}$ $\mathrm{cm}^{-2}$ ) are shown in Fig. 3a. Relevant photovoltaic parameters are collected in Table 2. For monomer-type sensitizers, DTFPy4 exhibites better cell performance parameters $\left(\eta=3.14 \% ; J_{\mathrm{sc}}=7.25 \mathrm{~mA} \mathrm{~cm}{ }^{-2}, V_{\mathrm{oc}}=626 \mathrm{mV}, \mathrm{FF}=\right.$ $0.69)$ compared to DTFPy3 $\left(\eta=2.74 \%\right.$; $J_{\mathrm{sc}}=6.96 \mathrm{~mA} \mathrm{~cm}^{-2}$, $\left.V_{\text {oc }}=607 \mathrm{mV}, \mathrm{FF}=0.65\right)$ as the adjusting of the $\pi$-bridge. Compared to their monomeric counterparts, both dimeric D-DTFPy3 and D-DTFPy4 exhibit enhanced photovoltaic performances under the similar fabricating and measuring conditions. With an enhanced $J_{\mathrm{sc}}$, the DSSC based on D-DTFPy 3 exhibits a higher $\eta$ of $4.03 \%$. The DSSC based on D-DTFPy4 shows the best photovoltaic performance with a $J_{\text {sc }}$ of $11.7 \mathrm{~mA} \mathrm{~cm}^{-2}$, a $V_{\text {oc }}$ of $630 \mathrm{mV}$, and an FF of 0.71 , corresponding to the $\eta$ of $5.26 \%$.

It is noted that the amount of the monomer-type sensitizers adsorbed on $\mathrm{TiO}_{2}$ is larger than that of the dimer-type

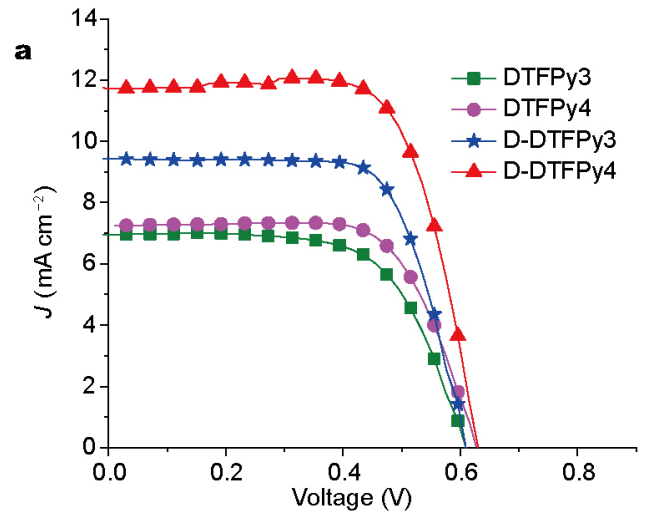

sensitizers, but the $J_{\mathrm{sc}}$ for the four sensitizers decreases in the order D-DTFPy4 $>$ D-DTFPy3 $>$ DTFPy4 $>$ DTFPy3 This result may be rationalized by the following reasons: (1) the dye adsorption is directly related to the structure and the molecular size of the sensitizers. Monomeric sensitizers DTFPy3 or DTFPy4 exhibit higher loading on the $\mathrm{TiO}_{2}$ surface, because they have smaller sizes; (2) each monomeric molecule of DTFPy3 or DTFPy4 contains only one light-harvesting unit, while each dimeric molecule of D-DTFPy3 or D-DTFPy4 has doubled light-harvesting units adsorbed on $\mathrm{TiO}_{2}$, which determines the light-harvesting efficiency and $\eta$ of the DSSC. Further study of the IPCE spectra confirmed the trend of $J_{\text {sc. }}$. Compared to the cells based on DTFPy3 and DTFPy4 with a narrow and relatively low IPCE values, the cells based on D-DTFPy3 and D-DTFPy4 exhibit remarkably broadened and increased IPCE action spectra covering the visible region from 400 to $550 \mathrm{~nm}$. The IPCE curve of D-DTFPy4 is slightly superior to that of D-DTFPy 3 in magnitude with values over $80 \%$ in the region of $400-450 \mathrm{~nm}$, which is much higher than that of DTFPy4 and DTFPy3 ( 60\%). The IPCE as a function of wavelength is directly related to the LHE, charge injection efficiency and charger collection efficiency. Considering the reducing amounts of adsorbed sensitizers from monomer-type sensitizers to dimer-type sensitizers as well as the same anchoring group for the

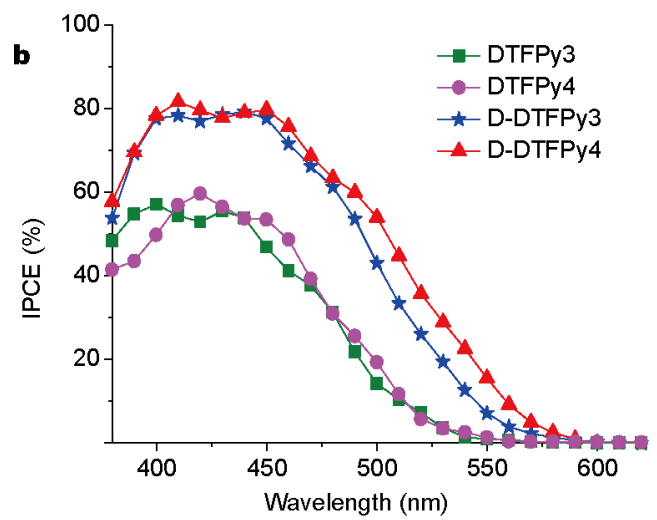

Figure 3 (a) $J$ - $V$ curves of DTFPy3, DTFPy4, D-DTFPy3 and D-DTFPy4 based DSCs, and (b) IPCE spectra of DTFPy3, DTFPy4, D-DTFPy3 and D-DTFPy4 based DSSCs.

Table 2 Properties of DTFPy3, DTFPy4, D-DTFPy3 and D-DTFPy4 based on DSSCs

\begin{tabular}{cccccc}
\hline Sensitizer & $J_{\text {sc }}\left(\mathrm{mA} \mathrm{cm}^{-2}\right)$ & $V_{\mathrm{oc}}(\mathrm{mV})$ & FF & $\eta(\%)$ & Dye absorbed amounts $\left(\mathrm{mol} \mathrm{cm}^{-2}\right)$ \\
\hline DTFPy3 & 6.96 & 607 & 0.65 & 2.74 & $(5.85 \pm 0.1) \times 10^{-8}$ \\
DTFPy4 & 7.25 & 626 & 0.69 & 3.14 & $(5.32 \pm 0.1) \times 10^{-8}$ \\
D-DTFPy3 & 9.43 & 611 & 0.70 & 4.03 & $(4.93 \pm 0.1) \times 10^{-8}$ \\
D-DTFPy4 & 11.70 & 630 & 0.71 & 5.26 & $(4.74 \pm 0.1) \times 10^{-8}$ \\
\hline
\end{tabular}


four sensitizers, a higher IPCE value for D-DTFPy4 can be ascribed to the higher light-harvesting efficiency.

\section{Electrochemical impedance spectroscopy analysis}

To further elucidate the photovoltaic results and display more dynamic information of the interfacial charge transfer process in DSSCs sensitized by DTFPy3, DTFPy4, D-DTFPy3 and D-DTFPy4, electrochemical impedance spectroscopy (EIS) was also performed in dark under a forward bias of $0.6 \mathrm{~V}$ with a frequency range of 0.1 $\mathrm{Hz}-100 \mathrm{kHz}$. In general, $R_{\mathrm{s}}, R_{\mathrm{rec}}$ and $R_{\mathrm{CE}}$ represent series resistance and charge transfer processes at the sensitizer/ $/ \mathrm{TiO}_{2} /$ electrolyte interface and counter electrode, respectively. $R_{\mathrm{s}}$ and $R_{\mathrm{CE}}$ show almost the same values in all the DSSCs, due to their same electrode and electrolyte. Moreover, the $R_{\text {rec }}$ corresponding to the larger semicircle is related to the charge recombination rate between the $\mathrm{TiO}_{2}$ film and the electrolyte. Generally, a larger $R_{\text {rec }}$ value indicates a slower charge recombination, thus giving a higher $V_{\text {oc. }}$. The Nyquist plots for the DSSCs based on the sensitizers are displayed in Fig. 4. The corresponding $R_{\text {rec }}$ values for DTFPy3, DTFPy4, D-DTFPy3 and D-DTFPy4 are 24.1, 25.3, 24.5 and 26.6 $\Omega \mathrm{cm}^{-2}$, respectively. The $R_{\mathrm{rec}}$ values trend in order of DTFPy $3<$ D-DTFPy 3 DTFPy4 $<$ D-DTFPy4 is in good consistent with the $V_{\text {oc }}$ results of these four sensitizers. Considering all of these four sensitizers have the same length of $\pi$-bridges, we hypothesize that the dimeric sensitizers D-DTFPy3 and D-DTFPy4 may adopt staggered molecular packing on $\mathrm{TiO}_{2}$ surface, thus leading to more efficient suppression of back reaction of the injected electrons with the redox electrolyte.

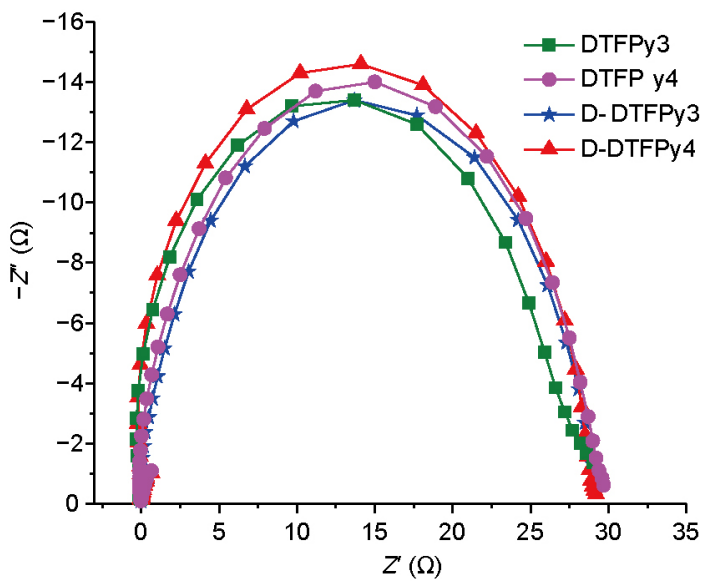

Figure 4 The Nyquist plots of DSSCs based on DTFPy3, DTFPy4, D-DTFPy 3 and D-DTFPy4.

\section{CONCLUSIONS}

In summary, two monobranched dithiafulvene based sensitizers using pyridine as acceptor (DTFPy3 and DTFPy4), and their corresponding dimeric congeners with two pinched D- $\pi$-A units (D-DTFPy3 and D-DTFPy4) were synthesized and tested in DSSCs. It was demonstrated that controlling the electron distribution in the $\pi$-bridges, such as arranging an electron rich thienyl group adjacent to the donor moiety and an electron poor phenyl group next to the acceptor moiety, could lead to red-shift of the absorption. Moreover, dimerization of the sensitizers with doubled light harvesting units could significantly enhance the absorption. As a result, D-DTFPy4, which features the dimeric $\mathrm{D}-\pi-\mathrm{A}$ units with thienyl-phenyl $\pi$-bridges between dithiafulvene donors and pyridine acceptors, has achieved the highest power conversion efficiency at $5.26 \%$ under standard AM 1.5 solar condition, mainly due to the relatively high light harvesting efficiency. These findings may pave a new path for developing high-performance DSSCs based on pyridine containing sensitizers.

Received 23 August 2016; accepted 20 September 2016; published online 19 October 2016

1 O'Regan B, Grätzel M. A low-cost, high-efficiency solar cell based on dye-sensitized colloidal $\mathrm{TiO}_{2}$ films. Nature, 1991, 353: 737-740

2 Grätzel M. Mesoscopic solar cells for electricity and hydrogen production from sunlight. Chem Lett, 2005, 34: 8-13

3 Li B, Wang L, Kang B, et al. Review of recent progress in solid-state dye-sensitized solar cells. Solar Energy Mater Solar Cells, 2006, 90: 549-573

4 Zhao Z, Liu G, Li B, et al. Dye-sensitized solar cells based on hierarchically structured porous $\mathrm{TiO}_{2}$ filled with nanoparticles. J Mater Chem A, 2015, 3: 11320-11329

5 Snaith HJ, Schmidt-Mende L. Advances in liquid-electrolyte and solid-state dye-sensitized solar cells. Adv Mater, 2007, 19: 3187-3200

6 Zhu K, Neale NR, Miedaner A, et al. Enhanced charge-collection efficiencies and light scattering in dye-sensitized solar cells using oriented $\mathrm{TiO}_{2}$ nanotubes arrays. Nano Lett, 2007, 7: 69-74

7 Zheng $\mathrm{X}$, Wei Z, Chen $\mathrm{H}$, et al. In-situ fabrication of dual porous titanium dioxide films as anode for carbon cathode based perovskite solar cell. J Energy Chem, 2015, 24: 736-743

8 Ning Z, Tian H. Triarylamine: a promising core unit for efficient photovoltaic materials. Chem Commun, 2009, 5483

9 Mishra A, Fischer MKR, Bäuerle P. Metal-free organic dyes for dye-sensitized solar cells: from structure: property relationships to design rules. Angew Chem Int Ed, 2009, 48: 2474-2499

10 Hagfeldt A, Boschloo G, Sun L, et al. Dye-sensitized solar cells. Chem Rev, 2010, 110: 6595-6663

11 Yella A, Lee HW, Tsao HN, et al. Porphyrin-sensitized solar cells with cobalt (II/III)-based redox electrolyte exceed 12 percent efficiency. Science, 2011, 334: 629-634

12 Qiu Y, Leung SF, Zhang Q, et al. Nanobowl optical concentrator for efficient light trapping and high-performance organic photovoltaics. Sci Bull, 2015, 60: 109-115

13 Qiu Y, Chen W, Yang S. Double-layered photoanodes from 
variable-size anatase $\mathrm{TiO}_{2}$ nanospindles: a candidate for high-efficiency dye-sensitized solar cells. Angew Chim Int Ed, 2010, 49: 3675-3679

14 Yan K, Qiu Y, Chen W, et al. A double layered photoanode made of highly crystalline $\mathrm{TiO}_{2}$ nanooctahedra and agglutinated mesoporous $\mathrm{TiO}_{2}$ microspheres for high efficiency dye sensitized solar cells. Energy Environ Sci, 2011, 4: 2168-2176

15 Liu T, Hou J, Wang B, et al. Correlation between the in-plain substrate strain and electrocatalytic activity of strontium ruthenate thin films in dye-sensitized solar cells. J Mater Chem A, 2016, 4: 10794-10800

16 Shen T, Tian J, Li B, et al. Ultrathin ALD coating on $\mathrm{TiO}_{2}$ photoanodes with enhanced quantum dot loading and charge collection in quantum dots sensitized solar cells. Sci China Mater, 2016, 59: $833-841$

17 Huo Z, Li T, Dai S, et al. Quasi-solid-state dye sensitized solar cells using supramolecular gel electrolyte formed from two-component low molecular mass organogelators. Sci China Mater, 2015, 58: $447-454$

18 Cheng J, Zhang F, Li K, et al. A planar dithiafulvene based sensitizer forming J-aggregates on $\mathrm{TiO}_{2}$ photoanode to enhance the performance of dye-sensitized solar cells. Dyes Pigments, 2017, 136: 97-103

19 Koumura N, Wang ZS, Mori S, et al. Alkyl-functionalized organic dyes for efficient molecular photovoltaics. J Am Chem Soc, 2006, 128: $14256-14257$

20 Imahori $\mathrm{H}$, Umeyama $\mathrm{T}$, Ito $\mathrm{S}$. Large $\pi$-aromatic molecules as potential sensitizers for highly efficient dye-sensitized solar cells. Acc Chem Res, 2009, 42: 1809-1818

21 Ito S, Miura H, Uchida S, et al. High-conversion-efficiency organic dye-sensitized solar cells with a novel indoline dye. Chem Commun, 2008, 5194

22 Zhang G, Bala H, Cheng Y, et al. High efficiency and stable dyesensitized solar cells with an organic chromophore featuring a binary $\pi$-conjugated spacer. Chem Commun, 2009, 2198

23 Feldt SM, Gibson EA, Gabrielsson E, et al. Design of organic dyes and cobalt polypyridine redox mediators for high-efficiency dyesensitized solar cells. J Am Chem Soc, 2010, 132: 16714-16724

24 Zeng W, Cao Y, Bai Y, et al. Efficient dye-sensitized solar cells with an organic photosensitizer featuring orderly conjugated ethylenedioxythiophene and dithienosilole blocks. Chem Mater, 2010, 22: 1915-1925

25 Cai N, Moon SJ, Cevey-Ha L, et al. An organic D- $\pi$-A dye for record efficiency solid-state sensitized heterojunction solar cells. Nano Lett, 2011, 11: 1452-1456

26 Choi $\mathrm{H}$, Shin $\mathrm{M}$, Song K, et al. The impact of an indeno[1,2-b] thiophene spacer on dye-sensitized solar cell performances of cyclic thiourea functionalized organic sensitizers. J Mater Chem A, 2014, 2: 12931-12939

27 Liu B, Wang B, Wang R, et al. Influence of conjugated $\pi$-linker in $\mathrm{D}-\mathrm{D}-\pi-\mathrm{A}$ indoline dyes: towards long-term stable and efficient dye-sensitized solar cells with high photovoltage. J Mater Chem A, 2014, 2: 804-812

28 Yao Z, Zhang M, Wu H, et al. Donor/acceptor indenoperylene dye for highly efficient organic dye-sensitized solar cells. J Am Chem Soc, 2015, 137: 3799-3802

29 Lee W, Yuk SB, Choi J, et al. The effects of the number of anchoring groups and $\mathrm{N}$-substitution on the performance of phenoxazine dyes in dye-sensitized solar cells. Dyes Pigments, 2014, 102: 13-21
30 Kim WR, Park H, Choi WY. Conical islands of $\mathrm{TiO}_{2}$ nanotube arrays in the photoelectrode of dye-sensitized solar cells. Nanoscale Res Lett, 2015, 10: 63

31 Zhang L, Cole JM. Anchoring groups for dye-sensitized solar cells. ACS Appl Mater Interf, 2015, 7: 3427-3455

32 Wei T, Sun X, Li X, et al. Systematic investigations on the roles of the electron acceptor and neighboring ethynylene moiety in porphyrins for dye-sensitized solar cells. ACS Appl Mater Interf, 2015, 7: 21956-21965

33 Chitpakdee C, Namuangruk S, Suttisintong K, et al. Effects of $\pi$-linker, anchoring group and capped carbazole at meso-substituted zinc-porphyrins on conversion efficiency of DSSCs. Dyes Pigments, 2015, 118: 64-75

34 Yang L, Yao Z, Liu J, et al. A systematic study on the influence of electron-acceptors in phenanthrocarbazole dye-sensitized solar cells. ACS Appl Mater Interf, 2016, 8: 9839-9848

35 Ooyama Y, Inoue S, Nagano T, et al. Dye-sensitized solar cells based on donor-acceptor $\pi$-conjugated fluorescent dyes with a pyridine ring as an electron-withdrawing anchoring group. Angew Chem Int Ed, 2011, 50: 7429-7433

36 Ooyama Y, Nagano T, Inoue S, et al. Dye-sensitized solar cells based on donor- $\pi$-acceptor fluorescent dyes with a pyridine ring as an electron-withdrawing-injecting anchoring group. Chem Eur J, 2011, 17: 14837-14843

37 Daphnomili D, Landrou G, Prakash Singh S, et al. Photophysical, electrochemical and photovoltaic properties of dye sensitized solar cells using a series of pyridyl functionalized porphyrin dyes. RSC Adv, 2012, 2: 12899-12908

38 Mao J, Wang D, Liu SH, et al. Dye-sensitized solar cells based on functionally separated $D-\pi$-A dyes with 2-cyanopyridine as an electron-accepting and anchoring group. Asian J Organic Chem, 2014, 3: $153-160$

39 Wang L, Yang X, Li S, et al. A new type of organic sensitizers with pyridine- $N$-oxide as the anchoring group for dye-sensitized solar cells. RSC Adv, 2013, 3: 13677

$40 \mathrm{Lu} \mathrm{J}, \mathrm{Xu} \mathrm{X}, \mathrm{Li} Z$, et al. Zinc porphyrins with a pyridine-ring-anchoring group for dye-sensitized solar cells. Chem Asian J, 2013, 8: 956-962

41 Ooyama Y, Yamaguchi N, Imae I, et al. Dye-sensitized solar cells based on D- $\pi-\mathrm{A}$ fluorescent dyes with two pyridyl groups as an electron-withdrawing-injecting anchoring group. Chem Commun, 2013, 49: 2548-2550

42 Bai Y, Zhang J, Zhou D, et al. Engineering organic sensitizers for iodine-free dye-sensitized solar cells: red-shifted current response concomitant with attenuated charge recombination. J Am Chem Soc, 2011, 133: 11442-11445

43 Cao D, Peng J, Hong Y, et al. Enhanced performance of the dye-sensitized solar cells with phenothiazine-based dyes containing double D-A branches. Org Lett, 2011, 13: 1610-1613

44 Hong Y, Liao JY, Cao D, et al. Organic dye bearing asymmetric double donor- $\pi$-acceptor chains for dye-sensitized solar cells. J Org Chem, 2011, 76: 8015-8021

45 Guo K, Yan K, Lu X, et al. Dithiafulvenyl unit as a new donor for high-efficiency dye-sensitized solar cells: synthesis and demonstration of a family of metal-free organic sensitizers. Org Lett, 2012, 14: 2214-2217

Acknowledgments This work was supported by the National Natural 
Science Foundation of China (21303117) and the Natural Science Foundation for Young Scientists of Shanxi Province (2014021014-3).

Author contributions Cao Y synthesized the dimeric sensitizers and performed the DSCs measurements. Cheng J synthesized the monomeric sensitizers. Zhang F assembled the solar cells. Liang X performed the CVs measurements. Li J provided the theoretical simulation. Guo K analyzed the results and wrote the paper. Yang $S$ supervised the research and revised the manuscript. All authors reviewed the manuscript.
Conflict of interest The authors declare that they have no conflict of interest.

Supplementary information The calculation of LHE, SEM images of $\mathrm{TiO}_{2}$ film, cyclic voltammograms and the absorption and PL spectra are available in the online version of this paper.
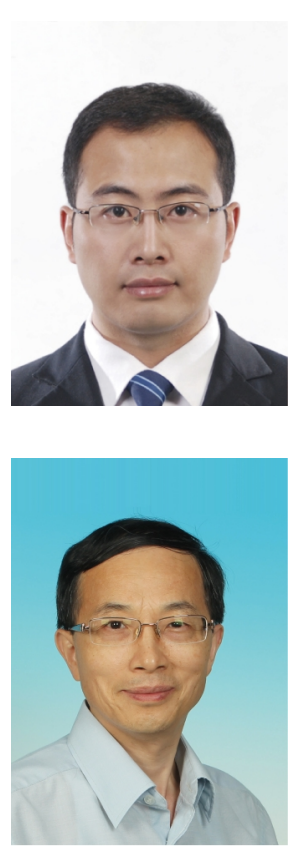

Kunpeng Guo is currently a professor at Taiyuan University of Technology. He received his BSc degree in chemistry from Shanxi University, and PhD degree in chemistry from the Key Laboratory of Photochemical Conversion and Optoelectronic Materials, Technical Institute of Physics and Chemistry, Chinese Academy of Sciences. Then, he joined Prof. Shihe Yang's group in Hong Kong University of Science and Technology as a postdoctoral researcher (Aug. 2010-Aug. 2012). In 2012, he joined the Research Center of Advanced Materials Science and Technology at Taiyuan University of Technology. His current research interests include organic light-harvesting materials, and organic luminescent materials.

Shihe Yang received his BSc degree in polymer chemistry/physics from Sun Yat-Sen University in China and PhD degree in physical chemistry in 1988 (with the Nobel Laureate Prof. Richard E. Smalley). He did post-doctoral research at Argonne National Laboratory and the University of Toronto (with the Nobel Laureate Prof. John C. Polanyi) before joining the faculty of Hong Kong University of Science and Technology, where he is currently a full professor. His research interests include chemistry and physics of finite systems, clusters, nanomaterials, and energy conversion. He and co-workers made contributions to the understanding and development of cluster science, fullerenes/metallofullerenes, novel nanomaterials chemistry, new generation solar cells, solar fuels, and other energy conversion devices. His current interest is focused on solar energy nanoscience and nanotechnology.

\section{分子工程优化含吡啶受体的二硫富瓦烯敏化剂用于高效染料敏化太阳电池}

曹亚雄 ${ }^{1}$, 成君 ${ }^{1}, 弓$ 芳 $^{1}$, 梁效中 ${ }^{1}$, 李洁 ${ }^{1}$, 郭婫鹏 $^{1^{*}}$, 杨世和 ${ }^{1,2^{*}}$

摘要 近年来, 具有给体- $\pi$ 桥-受体结构的有机化合物作为光敏剂用于染料敏化太阳电池的研究引起广泛关注. 研究发现吡啶作为电子受体 和吸附基团时可实现有效的电子注入. 为了提高含吡啶受体有机敏化剂的性能, 需要通过分子工程对电子给体, $\pi$ 桥和分子结构在分子层 面上进行优化. 本研究以二硫富瓦烯为电子给体, 吡啶为电子受体, 合成了两个 $\pi$ 桥结构分别为噻吩-苯和苯-噻吩的单体型敏化剂DTFPy3 和DTFPy4, 对二者及其对应的二聚体型敏化剂D-DTFPy3 和D-DTFPy4的研究发现, 调整 $\pi$ 桥上富电子噻吩靠近给体一端时可使敏化剂的 吸收波长红移. 另外, 二聚体型敏化剂可有效提高敏化剂的吸光强度. 在这四个敏化剂中, D-DTFPy4 表现出最佳的光捕获效率, 以其制备 的染料敏化太阳电池, 光电转换效率可达 $5.26 \%$. 